IJHS, e-ISSN 2597-4718, p-ISSN 2597-470X, Vol. 1, No. 1, September 2017, pp. 56-62

International Journal of Humanity Studies

IJHS

International Journal of Humanity Studies

http://e-journal.usd.ac.id/index.php/IJHS

Sanata Dharma University, Yogyakarta, Indonesia

\title{
MAKING PEACE AMONG CONFLICTING IDENTITIES: AN AUTOETHNOGRAPHY
}

\author{
Monica Ella Harendita \\ English Language Education Study Program \\ Faculty of Teachers Training and Education, Sanata Dharma University \\ meharendita@usd.ac.id \\ DOI: https://doi.org/10.24071/ijhs.2017.010106 \\ received 6 June 2016; revised 5 March 2017; accepted 8 July 2017
}

\begin{abstract}
Autoethnography has gained more popularity in qualitative research. Putting the researcher's personal narratives at the centre, authoethnography can present one way to vocalize her voice without diminishing the significance of theories. By connecting lived experiences with the framework, autothnography can serve as a powerful tool in meaning makings. Drawn upon my experiences when I was pursuing my master's in Australia, this autoethnography portrays my struggle on identity negotiation as a Javanese woman and a student in Australia. As I was trying to uncover my experiences and look at them mainly using Hall's (1993, 1997) theories as the framework, I came into a better understanding on my multiple and multilayered identities. Negotiating those identities is the key to make peace among them.
\end{abstract}

Keywords: identity negotiation, autoethnography, experiences, reflexivity

\section{Introduction}

Autoethnography is defined as "a reflexive means by which the researcherpractitioner consciously embeds himself or herself in theory and practice" (Mcllveen, 2008, p. 13). Furthermore, it aims to describe and analyse personal experience so as to understand cultural experience (Ellis, Adams, \& Bochner, 2011, p. 273). Autoethnography thus can be seen as an approach and a product. It is also referred to as personal narrative and reflexivity. Autoethnography is therefore personal, intimate, and transformative in nature.

Rooted in my experiences when I was a student in Australia, this autoethnography serves as my critical interpretation of the experiences I encountered as a Javanese cultural member and "an outsider" in Australia. I will begin by reviewing how language, identity, and cultural difference are closely connected according to Hall $(1993,1997)$. Secondly, using Hall's ideas of representation, I will give some accounts on how a Solonese woman has been represented through Putri Solo, a well-known Javanese song. As a Javanese, particularly Solonese woman, I consider it important to discuss such representation as I have experienced how the song produces meanings in society 
which become the basis of identifying a Solonese woman. Thirdly, I will scrutinize how I negotiate my multiple identities as a Javanese Indonesian and as an International student in Australia. Lastly, I will provide a brief elaboration on how writing this autoethnography has helped me see language, identity, and cultural difference using a new perspective.

\section{Theory}

Hall (1997) accounts for how language, culture, and identity are closely interrelated. He defines language in a much broader and distinct sense from the general view of language. He states that language is not simply a matter of linguistic codes. Rather, it is any sign or symbol (sound, image, word, etc) which carries meanings. Meanings are neither inherited in things or objects nor neutral. To elaborate this, Hall (1997, p. 26) provides "the language of traffic lights" as an example. 'Red', if taken out from any contexts, does not mean anything in itself. However, when 'red' is situated in traffic lights, it works as a language which signifies 'stop'. Thus, meanings are constructed by members of a particular culture through the system of representation which works in language. In other words, representation is the key enabling language to work and concepts to be represented through signs. The relationship between signs and concepts is, therefore, arbitrary.

Hence, culture and meaning are closely related in a sense that cultural members generate and exchange meanings through their social practices and, therefore, they are able to see the world in more or less the same ways. This is what Hall (1997) points out as "shared meanings" (p. 1). Meanings are also central to culture as they set the rules of social practices. How we consume meanings and give meanings to ourselves will also contribute to our identities. Culture, thus, plays an important role for a cultural member to give meanings to himself/herself, which consequently represents his/her identity. On the whole, both language and culture become the media through which meanings are produced and circulated. Besides, Hall (1997) argues that since language makes it able for meanings to be constructed and transmitted, language serves as "the key repository of cultural values and meanings" (p. 1) as these values and meanings can only be shared through a "common access to language" (p. 1).

Therefore, meanings are not fixed but keep changing depending on the context, "relational" (p. 27) and "always only partially understood" (p. 4). Representation through which meanings are made seems to be two-way communication or "dialogic" (p. 10), which denotes the presence of negotiation. However, it is through power that some parties endeavour to fix meanings. Closely attached to meanings, identity is therefore also fluid as well as keeps being negotiated and struggled.

In Cultural Identity and Diaspora, Hall (1993) challenges the view seeing cultural identity as 'oneness' and unchanging. As a poststructuralist, he emphasises that cultural identity is attached to histories and undergoes constant transformation, which strengthens his view of the fluidity of identity. In addition, as difference can signify meanings (Hall, 1997), identity is also "forged through the marking of difference" (Woodward, 1997, p. 29). Members of cultural group can identify themselves as belonging to certain culture or group since they can, in 
the first place, see the difference between them and other culture's members. In addition, cultural identity is also related to feelings, attachments, and sense of belonging.

To put it briefly, language works as a system of representation, through which meanings are constructed and circulated in culture resulting in identity formation. Therefore, identity is fluid, not fixed, and multiple. Thus, it is essential for cultural members to have an understanding on how the three notions are interrelated as they are inseparable parts of society which become the basis of how society runs their life.

\section{Theory Application}

Indonesia as the world's largest archipelago country consists of approximately 17,000 islands, hundreds of ethnic groups and local languages, which confirm its multilingual and multicultural nature. Java Island, as the third largest island in Indonesia, is inhabited by $60 \%$ of the total population of the country. As a Javanese cultural member who was raised in Solo, a small city in Central Java province, I have seen a number of practices through which representation takes place within the culture. One of the aspects closely attached to Solo is the representation of Putri Solo. When I introduced myself as a Javanese, particularly Solonese, a stereotype usually arose. They would guess and generalise that as a Solonese woman, I must be polite and gentle as represented by a quite famous Javanese kroncong song titled 'Putri Solo'. One of the lyrics can be translated into 'a Solonese lady walks as gently as a hungry tiger does'. Another line in the lyrics representing the virtues of Putri Solo is 'dasare kepara nyata, pancen pinter alelawa', which means that it is true that she is fashionable and has good manners.

According to Hall (1997), cultural meanings "organize and regulate social practices, influence our conduct and consequently have real, practical effects" ( $p$. 3 ). The song exerts a system of representation through which cultural meanings are generated and circulated within Javanese society. Based on the circuit of culture (du Gay, Hall, et al., 1997 in Hall, 1997), the representation circulates meanings which are then consumed and contribute to identity formation. For years, the meanings represented through the lyrics have brought Javanese people in general to set regulations of what Solonese women should do. Politeness, gentleness, and good manners are three aspects expected from Javanese women. Accordingly, the representation serves as a powerful justification to categorize me and Solonese women in general as having the same characteristics, resulting in a stereotype about Solonese women. Besides, not just confined to Solonese women, Putri Solo has also been used to label women, not necessarily from Solo, who seem to have the virtues depicted in the lyrics. In short, this representation sets out what is normal and what is not. Admittedly, women who do not seem to have the above characteristics will be considered as breaching the norms or as not belonging to the culture.

The identity being projected in the song was probably true in the era when the song was created. The image of Putri Solo in the song seems to portray a typical Solonese lady in the reign of Mataram Kingdom which may become the basis for the song writer to compose such lyrics. The history of Solo itself is 
inseparable from Mataram Kingdom, by which Solo was governed before Indonesia proclaimed its independence in 1945. However, since "identity is being formed in particular historical circumstances" (Woodward, 1997, p. 3), the representation of Putri Solo is now being contested. In the contemporary world in which the effect of assimilation of national culture as well as globalisation is noteworthy across the country, Solonese women's characteristics seem to be very diverse, and therefore may not fit the description in the lyrics. This phenomenon actually depicts identity as fluid and keeps being transformed (Hall, 1997). Yet, Javanese people paradoxically often come to a conclusion that there has been a "crisis of identity" (Woodward, 1997, p. 16) among Javanese, particularly Solonese, without recognising the changes taking place in society. As a matter of fact, this assumption of identity crisis tends to cling to the view which sees identity as fixed and unchanging.

To sum up, the representation of Putri Solo has enunciated how the signifying practice contributes to the meanings generated and shared in Javanese culture. The production, consumption, and regulation of meanings have therefore contributed to the identity formation of Solonese women as being polite, gentle, and well-mannered without taking into account some major changes within the culture.

$$
\begin{array}{ll}
X & : \text { Are you Chinese? } \\
\text { Me } & : \text { No, I'm Indonesian. } \\
X & : \text { Are you Chinese Indonesian? } \\
M e & : \text { No, I'm a Javanese Indonesian. }
\end{array}
$$

The above conversation was a real dialogue that I had with an acquaintance when I was fairly new in Melbourne. In a multicultural country like Australia, it is somehow a very common practice to ask people, let alone 'new comers', where they are from. It will be even more surprising if the person is not really satisfied with the answer they are given as depicted in the dialogue. I understand that "the physical body is one site which might both set the boundaries of who we are and provide the basis of identity" (Woodward, 1997, p. 13). Yet, it struck me still that the one I spoke to often judged me by my appearance. I admit that among Indonesians, particularly Javanese Indonesians, I might look a little bit different, most likely in terms of my complexion which is paler than the majority of Javanese people. However, what they could not see is how much I feel attached to Javanese culture and the process I have been through as a Javanese Indonesian.

"Although there is no one-to-one relationship between anyone's language and his or her cultural identity, language is the most sensitive indicator of the relationship between an individual and a given social group." (Kramsch, 1998, p. 77). As a Javanese Indonesian, I somehow maintain my identity as a Javanese through the use of Javanese language along with the increasing use of Indonesian language (Bahasa Indonesia) within the society. This preservation originated from the values I learned from both my extended family, who are in many senses 'very Javanese', and my parents in particular. The act of preserving Javanese-ness is done by the use of krama in my family, especially in child-parent conversation. In my generation, not many among my friends still speak krama to their parents. 
My friends who visited me sometimes expressed their surprise that I was speaking krama to my parents, while they preferred speaking in Bahasa Indonesia if not ngoko to their parents. As my second language and the official language of Indonesia, Bahasa Indonesia offers more flexibility since it is not hierarchical and only uses one speech level (Moedjanto, 1986). However, although I am competent in it, I personally do not feel myself attached to it as much as I feel to Javanese. This feeling of attachment, I believe, contributes to how I identify myself.

However, preserving identity is not without conflicts. For example, I was not comfortable using 'bapak' and 'ibu' when I was still in primary school because most of my friends used 'papa' (father) 'mama' (mother) in referring to their parents. What was in my mind when I used 'bapak' and ' $i b u$ ' was the feeling of inferiority as I maintained my Javanese-ness. Hall (1997) states that various media help produce meanings. In light of this, 'papa' (father) and 'mama' (mother) have become widely used as they appear very frequently in mass media and advertisements. The words 'mama' and 'papa' themselves are not the socalled 'standard' Bahasa Indonesia as the Indonesian words are 'ayah' for 'father' and 'bunda' for 'mother'. Coming from outside the country, 'papa' and 'mama' have been globalised and adopted by many Indonesians, especially those from higher social class. The consumed meanings and sense of more modernity that 'papa' and 'mama' retain had resulted in my being less confident in using 'bapak' and ' $i b u$ ' because the words probably signified inferiority in my friends' eyes.

According to Woodward (1997), the globalisation may cause either detachment of local/national identities or resistance. In my case, it can be seen that my parents chose to resist the globalised ' $p a p a$ ' and 'mama' by teaching us to call them using our local language, 'bapak' and 'ibu'. Kramsch (1998) argues that 'to identify themselves as members of community, people have to define themselves jointly as insiders against others, whom they thereby define as outsiders" (p. 8). Despite the discomfort I felt as a child in using the words, I still asserted my Javanese identity although somehow I felt that I was an outsider and the 'Other' (Hall, 1997, p. 56). I was actually exercising power through my use of language, which, as Fairclough (1989) states, resulted in my involvement "in struggle with others" to defend my position (p. 35). However, my being not confident, then, has completely vanished alongside my adolescence, which indicates a stronger sense of belonging to Javanese culture. I am now even very proud that I still maintain using 'bapak' and 'ibu'.

Ferzacca (2006) points out that "one of the important markers of being a person the Javanese way is to be sopan santun" (p. 343) which means 'polite'. Besides, as a Javanese I was also taught to respect people, particularly with the use of krama to them, particularly if they are older than me. Politeness and respect can be seen as the manifestation of Javanese etiquette, andap asor (Setiawan, 1998). A Javanese may consider whether it is the age, social status, or intimacy which is important for him/her most in certain discourses or social practices. These three aspects are actually intertwined that it is sometimes difficult to decide the right register. For example, when I was still living with my parents, our neighbours generally spoke krama to me although in terms of age, they were much older than me. In this case, they were positioning themselves as having lower social status and thought that it was the most important aspect to be 
considered in our discourse. I, myself, spoke krama to them since I was taking their ages into consideration. From the examples, it can be seen that both my neighbours and I practised andap asor which has bound our conducts and social practices as Javanese.

This value of respecting older people was challenged in the first few weeks upon my arrival in Australia. Although in my cross-cultural understanding class prior to my departure to Australia, the teacher already stated that Australians had a very casual way of addressing people, it was still an awkward moment for me to call my lecturers by their first names, without any Miss or Mister or even Doctor before their names. When I sent my first email to my lecturer, I was very confused to decide how to address him. Then, I decided to put Mr. followed by his full name as I thought I would have 'sinned' to my identity as a Javanese if I had not done it. Surprisingly, in his reply, he asked me to call him by his first name; something that I had never done to any of my teachers.

Yet, as I had been used to the new culture, I realised that some parts of my subjectivity had shifted. I was then comfortable to call my lecturers and my classmates who are from different parts of the world by their names. However, it was not because I did not call people by their title that I had lost my Javaneseness. As identity is not fixed, multiple, and is a matter of positioning (Hall, 1997), what I was undergoing was the negotiation of my identities as a Javaness and as an 'outsider' in Australian context. To some extent, I have learned how calling someone by his/her first name without any title actually works as a representation of how equality is upheld in Australian culture. Besides, although title is not frequently used, it does not mean that the sign of respect is not enunciated through English language in Australia. I had seen a lot of practices there in which 'thank you' and 'please' were often spoken to signify respect for others. In spite of my being used to calling people by their first names, I still continued to call my Indonesian friends who lived there with 'Mbak' (sister), 'Mas' (brother), 'Bu' (Ms./Mrs.), 'Pak' (Mr.), as a sign of respect. In that case, I was negotiating the meanings which results to different positioning.

\section{Conclusion}

The complexity of identity should be seen as having no clear cut definition, and stereotyping, although somehow inevitable, definitely does not apply in defining one's identity. Although people's complexion may speak as a language and their accent can signify certain meanings, it should not be a justification to stereotype them. It is neither our appearance nor the language we speak which tells who we are, but the feelings of attachment and belongingness. Besides, the identity is not a single entity as it is multiple, fluid, and constantly changing.

In my case, it is not when I say 'Indonesian' that people can recognise me as an Javanese Indonesian who has been through a long and never-ending process in shaping my identity. While preserving my Javanese-ness, I at the same time negotiated my identities as an Indonesian studying in Australia, a former English teacher, a learner of English, a woman, and many others. It is then essential for me to know how to position myself depending on the context as well as keep adjusting to new situations. Similar processes, or even much more complex ones, 
happen to every single person in this world which makes it impractical to see identity as one, fixed, and unchanging.

On the whole, this autoethnography has attempted to see how language, culture, and identity are intertwined through my past experiences. Hall's (1997) notion of representation has shed light on how Putri Solo circulates meanings which contribute to identity formation, as well as my shifted subjectivity as a Javanese Indonesian and an international student. I myself have also come to a different perspective in seeing language, culture, and identity which, I am sure, will be an invaluable asset for me as a cultural member and an English language teacher in particular.

\section{References}

Ellis, C., Adams, T. E. \& Bochner, A. P. (2011). Autoethnography: An overview. Historical Social Research, 36(4), 273-290.

Fairclough, N. (1989). Language and power. London: Longman Group UK Limited.

Ferzacca, S. (2006). Learning how to listen: Kroncong music in a Javanese neighbourhood. Sense \& Society, 1(3), 331-358.

Hall, S. (1993). Cultural identity and diaspora. In P. Williams \& L. Chrisman (Eds.). Colonial discourse and post-colonial theory: A reader (pp. 392-403). Hemel Hampstead: Harvester Wheatsheaft.

Hall, S. (1997). Representation: Cultural representations and signifying practices. London: Sage Publications Ltd. \& the Open University.

Kramsch, C. (1998). Language and culture. Oxford: Oxford University Press.

Mcllveen, P. (2008). Autoethnography as a method for reflexive research and practice in vocational psychology. Australian Journal of Career Development, $17(2), 13-20$.

Moedjanto, G. (1986). The concept of power in Javanese culture. Yogyakarta: Gajah Mada University Press.

Setiawan, A. (1998). Perilaku birokasi dalam pengaruh paham kekuasaan Jawa. Yogyakarta: Pustaka Pelajar.

Woodward, K. (1997). Identity and difference. London: Sage Publications Ltd. \& the Open University. 